\title{
Growth response and nutrient digestibility of growing pigs to qualitative and quantitative feed restriction
}

Njoku*, C. P.,Adeyemi,O. A.,Egbeyale,L.T.,Sanya,B.J.,Situ, R.O.and Osinaike,O.G. Department of Animal Production and Health, University of Agriculture, Abeokuta,

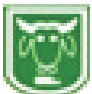

Nigeria

*Corresponding author:ncfred0859@yahoo.co.uk

\begin{abstract}
Feed restriction is a relevant management tool use in modificationof livestock growth patterns by reducing their maintenance requirement, leading to improved feed efficiency and utilization. This study assessed the effect of qualitative and quantitative feed restriction on growth parameters and nutrients digestibility of growing pigs. Fifty four (54) mixed breed pigs with initial body weight of $6.72 \pm 0.38 \mathrm{~kg}$ were arranged in a $3 \times 3$ factorial arrangement for a 150-day study: Factor A consists of 3 levels of qualitative feed restriction $(20 \%, 18 \%$ and $16 \%$ crude protein) and Factor B consists of 3 levels of quantitative feed restriction (adlibitum, $90 \%$ and $80 \%$ of ad-libitum feed offered). The experimental animals were grouped on weight equalization into 9 treatment groups of 3 replicates of 2 pigs per replicate. Growth performance data were collected on weekly basis and nutrient digestibility was carried out on the $11^{\text {th }}$ week of the experiment. Data obtained were subjected to two-way analysis of variance. Final body weight, daily weight gain and daily feed intake were significantly $(p<0.05)$ influenced by increment in dietary crude protein. The pigs fed 20\% crude protein recorded the best FCR of 1.36. Quantitative feed restriction had no influence on the growth parameters studied. Feed quality and quantity offered had significant $(P<0.05)$ influence on excreted faeces, faecal dry matter output, excreted faeces/dry matter intake, dry matter digestibility, crude protein digestibility, ether extract, crude fibre digestibility and ash. Similar (P>0.05) mean values of excreted faeces, faecal dry matter output, excreted faeces/ dry matter intake, crude protein digestibility, crude fibre digestibility, ash and ether extract were recorded for pigs fed $18 \%$ and $16 \%$ of crude protein respectively. It can be concluded from this study that a combination of qualitative and quantitative restriction (at 18\% crude protein with $80 \%$ of ad libitum feed offered) can be used as management tool to improve feed utilization in growing pigs.
\end{abstract}

Keywords: Qualitatıve, quantitatıve, restriction, growth, nutrients, pigs

\section{Introduction}

Nutrients requirement is defined as the minimum amount of nutrients that is integrated into ration to meet the daily requirement of a normal healthy animal (Scott et al., 1989). Nutrient remains the most vital single factor under the environment which plays a significant role since it accounts for $70-75 \%$ of total variable cost of production of poultry, rabbits and pigs (Njoku et al., 2013). Nutrition entails the process of supplying the body cells of an animal with the quota of the external environment required for optimum functioning of metabolic chemical reaction requisite for growth and development. A balanced nutrient is a key to a successful livestock production as it provides animal with energy and nutrients 
that are essential for health and efficient production. Feeding livestock with incorrect or unbalanced nutrient will result to a negative influence on final body weight, feed efficiency and carcass fat that might lead to processing difficulties. Feed intake is phenotypically positively correlated with other important economic traits such as growth rate and backfat composition (Caiet al., 2008; Hoqueet al., 2009). Genetic improvement has resulted to loss of sensitivity to regulate feed intake especially in fast growing farm animals like pigs and broiler chickens. Richards (2003) postulated that livestock species selected for rapid weight gain and muscular mass deposition do not regulate their voluntary feed intake under ad libitum feed management; they show irrational appetite and excessive fat accumulation.

Management practices leading to improve feed efficiency in pig production is essential, asprofitability in pig industry is dependent on the efficiency of feed conversion, price of feed, pig genotype and the price for market pigs at a particular time. Feed restriction is one of the management practice used to modify the patterns of livestock growth by reducing their maintenance requirement leading to improved feed efficiency. It is the act of denying fast growing animal full access to nutrient required for tissue growth and development. It helps to reduce the problem of sudden death syndrome (Gonzales et al., 1999), decreased back fat composition, lower cost of production and feed conversion ratio(Njokuet al., 2012).Feed restriction includes quantitative and qualitative restriction, i.e. a quantitative restriction involves limiting the amount of daily feed offered to an animal whereas a qualitative restriction is related to nutrient dilution in the ration
(Lesson and Zubar, 1997). To date, studies on feed restriction were mostly conducted in the temperate region of the world, with little information on the tropical hot humid environment. The purpose of this study was to validate the effects of quantitative and qualitative feed restriction on the growth performance and nutrients digestibility of growing pigs raised under hot humid environment.

\section{Materials and Methods}

The experimental protocols involving the use of animals were in compliance with the animal welfare requirements for care and management of experimental animal and was approved by the Animal Welfare Committee of the Federal University of Agriculture, Abeokuta Experimental Site

The experiment was carried out at the Piggery Unit of the Teaching and Research Farms Directorate (TREFAD), Federal University of Agriculture, Abeokuta, Ogun State, Nigeria. The farm lies within latitude $7^{\circ} 10^{\prime} \mathrm{N}$, longitude $3^{\circ} 2^{\prime} \mathrm{E}$ and altitude 76 $\mathrm{mm}$. It is located in the derived savannah zone of South-Western Nigeria. It has a humid climate with mean annual rainfall of about $1037 \mathrm{~mm}$ and temperature of about $34.7^{\circ} \mathrm{C}$. The relative humidity ranges from 63 to $96 \%$ in the rainy season (late March to October) and from 55 to $82 \%$ in the dry season (November to early March) with an annual average of $82 \%$. The seasonal distribution of annual rainfall is approximately $44.96 \mathrm{~mm}$ in the late dry season (January-March); $212.4 \mathrm{~mm}$ in the early wet season (April-June); $259.3 \mathrm{~mm}$ in the late wet season (July-September) and $48.1 \mathrm{~mm}$ in the early dry season (OctoberDecember) as documented by Federal University of Agriculture, Abeokuta Meteorological Station. 
Experimental Animals and Management A total of fifty four (54) mixed breed pigs weighing $6.72 \pm 0.38 \mathrm{~kg}$ were bought from reputable farm within Abeokuta metropolis. The pigs were grouped on weight equalisation into (9) treatments with 3 replicate of 2 pig per replicate. The floor of the housing unit was washed with detergent and disinfectant, the pen was repaired and put into good working conditions before the arrival of the experimental animals. On arrival the pigs were given water and feed containing antistress and multi-vitamins. The pigs were injected with ivomec ${ }^{\circledR}$ (ivermectine) against endo and ecto-parasites and allowed to acclimatize for one week (7days) before the commencement of the experiment. The pen has a floor area of $3 \mathrm{~m}$ by $2 \mathrm{~m}$, equipped with concrete feeding and watering trough. The pens are half-walled of about 1.4-1.6 m high and the rest are open-sided for proper ventilation. Daily routine management practices were carried out on daily basis, fresh water was supplied ad libitum throughout the 150 days experimental period.

\section{Experimental Design}

The experimental design was a $3 \times 3$ factorial arrangement with factor $A$ consisting of three (3) levels of qualitative feed restriction $(20 \%, 18 \%$ and $16 \%$ crude protein) and factor B involving quantitative feed restriction (ad libitum, 90\% and 80\% of ad-libitum feeding). Treatment 1 consists of pigs fed ad libitum with daily ration containing $20 \%$ crude protein, group 2 was fed ad libitum with daily ration containing $18 \%$ crude protein, group 3 was fed ad libitum with daily ration containing $16 \%$ crude protein, group 4 consists of pigs on $90 \%$ of ad-libitum feeding with $20 \%$ crude protein ration, group 5 was fed $90 \%$ of adlibitum feeding with $18 \%$ crude protein ration, group 6 was fed with $90 \%$ of ad- libitum feeding with $16 \%$ crude protein ration, group 7 consists of pigs on $80 \%$ of ad-libitum feeding with $20 \%$ crude protein ration, group 8 was fed $80 \%$ of ad-libitum feeding with $18 \%$ crude protein ration, and group 9 was fed $80 \%$ of ad-libitum feeding with $16 \%$ crude protein ration.

Experimental Diets

Three experimental diets were formulated to meet the body requirements of growing pigs as shown in Table 1 . The ration contained $20 \%, 18 \%$ or $16 \%$ crude protein and metabolisable energy of 2530.50, 2474.39 or $2403.30 \mathrm{kcal} \mathrm{DE} / \mathrm{kg}$ (Auto Feed Formulator, NRC) for diets 1,2 and 3 respectively. Feed was offered to the experimental pigs at 08:00 hour dailythroughout the experimental period.

\section{Data Collection} Initial body weight of the pigs were taken using weighing scale with a $0.05 \mathrm{~g}$ precision at the beginning of the experiment and weekly records of change in body weight were subsequently taken and documented. Feed intake was determined daily by subtracting the feed left-over from the feed supplied. The feed conversion ratio was calculated as:

\section{Feed Conversion Ratio \\ $=\underline{\text { Average Feed Intake }(\mathrm{kg} / \mathrm{pig})}$ \\ Average Daily Weight Gain (kg/pig)}

\section{Digestibility Study}

On the $11^{\text {th }}$ week of the experiment, the animals were moved into metabolic cages already cleaned and disinfectant for determining their nutrients digestibility. A 7-day adaptation period followed by a 5day of quantification of feed intake and excreted faeces. Faeces were collected quantitatively and stored in a freezer until analyzed. After the collection periods,faeces were thawed, homogenized and dry in a forced cabinet. Sub-samples of 
Growth response of growing pigs to qualitative and quantitative feed restriction

Table 1: Percentage composition of experimental diets

\begin{tabular}{|c|c|c|c|}
\hline Ingredients & Diet 1 & Diet 2 & Diet 3 \\
\hline Maize & 29.00 & 40.00 & 45.50 \\
\hline Groundnut cake & 18.00 & 13.00 & 8.00 \\
\hline Wheat offal & 30.00 & 20.00 & 19.05 \\
\hline Palm kernel cake & 19.65 & 23.65 & 24.10 \\
\hline Bone meal & 2.60 & 2.60 & 2.60 \\
\hline Salt & 0.35 & 0.35 & 0.35 \\
\hline Lysine & 0.05 & 0.05 & 0.05 \\
\hline Methionine & 0.05 & 0.05 & 0.05 \\
\hline *Premix & 0.30 & 0.30 & 0.30 \\
\hline Total & 100.00 & 100.00 & 100.00 \\
\hline \multicolumn{4}{|c|}{ Determined Analysis (\%) } \\
\hline Crude protein & 20.30 & 18.00 & 16.16 \\
\hline Fat & 6.81 & 7.34 & 7.26 \\
\hline Crude fibre & 5.09 & 4.47 & 4.25 \\
\hline Calcium & 0.77 & 0.79 & 0.84 \\
\hline M.E (Kcal/kg feed) & 2677.50 & 2870.09 & 2932.37 \\
\hline
\end{tabular}

$200 \mathrm{~g}$ (faeces) were taken and stored frozen until analyzed. The frozen faeceswerethawed and oven-dried, the oven dried faeces and feed materials were milled to $2 \mathrm{~mm}$ particle size and analyzed for their proximate constituents following AOAC(2005) protocols, the dry matter of the samples was determined by drying at $105^{\circ} \mathrm{C}$ for four hours. The crude protein $(\mathrm{CP})$ concentration of samples was determined by the Kjeldahl method and the ether extract by a Soxhlet apparatus. The crude fibre(CF) concentration was determined using trichloroacetic acid digestion reagent and concentration of ash wasdetermined by incinerating samples at $550^{\circ} \mathrm{C}$ for 5.5 hours. The data obtained from digestibility studies wasused for the calculation of dry matter, crudeprotein, ether extract, ash and crude fibre digestibilities. The digestibility of dry matter and nutrients was calculated using the following formula:

Dry matter digestibility is thus calculated as:

Dry matter digestibility $(\mathrm{kg})=$ Feed intake $(\mathrm{kg} / \mathrm{Dm})-$ Faecal output $(\mathrm{kg} / \mathrm{Dm})$ Feed intake (Kg/DM)
Nutrient digestibility (\%)

$=\underline{\text { Nutrient in feed }- \text { Nutrient in faeces X } 100}$ Nutrient in feed

\section{Statistical Analysis}

The experimental layout was a $3 \times 3$ factorial arrangement. Data generated weresubjected to a two-way Analysis of Variance using SAS (2000). Significantly $(\mathrm{P}<0.05)$ different means among the variables were separated using New Duncan Multiple Range Test as contained in the same statistical package.

\section{Results}

Effect of qualitative feed restriction on growth performance of growing pigs

Table 2 shows the effect of qualitative feed restriction on performance of growing pigs. Significant $(p<0.05)$ differences were observed across all parameters considered. Pigs on $20 \%$ dietary protein had the highest final weight value of $43.00 \mathrm{~kg}$ compared to $38.44 \mathrm{kgand} 35.22 \mathrm{~kg}$ documented for those on $18 \%$ and $16 \%$ dietary protein levels, respectively. Pigs on $20 \%$ protein restriction level recorded the highest weight 
Table 2: Effect of qualitative restriction on growth performance of growing pigs

\begin{tabular}{lllll}
\hline Parameters/Qualitative Restriction & $20 \%$ & $18 \%$ & $16 \%$ & SEM \\
\hline Initial weight (kg/pig) & 6.78 & 6.83 & 6.56 & \pm 0.38 \\
Final weight (kg/pig) & $43.00^{\mathrm{a}}$ & $38.44^{\mathrm{ab}}$ & $35.22^{\mathrm{b}}$ & \pm 1.91 \\
Weight gain (kg/pig) & $36.22^{\mathrm{a}}$ & $31.61^{\mathrm{ab}}$ & $28.67^{\mathrm{b}}$ & \pm 1.74 \\
Daily weight gain (g/pig) & $345.00^{\mathrm{a}}$ & $301.06^{\mathrm{ab}}$ & $273.02^{\mathrm{b}}$ & \pm 0.02 \\
Feed intake (kg/pig) & $55.81^{\mathrm{a}}$ & $43.39^{\mathrm{b}}$ & $40.17^{\mathrm{b}}$ & \pm 3.60 \\
Daily feed intake (g/pig) & $531.56^{\mathrm{a}}$ & $413.21^{\mathrm{b}}$ & $382.54^{\mathrm{b}}$ & \pm 0.03 \\
FCR & $1.36^{\mathrm{b}}$ & $1.40^{\mathrm{ab}}$ & $1.53^{\mathrm{a}}$ & \pm 0.05 \\
\hline
\end{tabular}

${ }^{\text {ab- }}$ Values with different superscripts within rows are significantly different $(\mathrm{P}<0.05)$

gain of $36.22 \mathrm{~kg}$ while the least value of 28.67 kgwas documented for pigs on $16 \%$ dietary protein. Similar statistical values were observe for feed intake and daily feed intake of pigs fed $16 \%$ and $18 \%$ dietary protein level which differed significantly $(\mathrm{P}<0.05)$ from the value obtained for pigs on $20 \%$ dietary protein level. Feed conversion ratio decreased significantly $(\mathrm{P}<0.05)$ with increase in dietary protein, with the best value of 1.36 noted for pigs on $20 \%$ dietary protein while the worst value of 1.53 was documented for pigs on dietary crude protein level of $16 \%$.

Effect of quantitative restriction on growth performance of growing pigs

The final weight, weight gain, daily weight gain, feed intake, daily feed intake were not significantly $(p>0.05)$ influenced by quantitative feed restriction as depicted in Table 3. Initial body weight was not significant.
Interaction between qualitative and quantitative feed restriction on performance of growing pigs

Table 4 shows the interaction between the qualitative and quantitative feed restriction on growth performance. Final weight, weight gain, daily weight gain were not significantly $(p<0.05)$ influenced by the interaction between quantitative and qualitative feed restriction while feed intake, daily feed intake and FCR were significantly $(\mathrm{p}<0.05)$ influenced. The pigs fed $20 \%$ dietary protein at ad libitum recorded highest values of feed intake, daily feed intake and FCR.

Effect of Qualitative Feed Restriction on Nutrient Digestibility of Growing Pig

Effect of qualitative feed restriction on nutrient digestibility is shown in Table 5. Feed intake and dry matter intake were not significantly $(\mathrm{P}>0.05)$ influenced by the

Table 3: Effect of quantitative restriction on growth performance of growing pigs

\begin{tabular}{lllll}
\hline $\begin{array}{l}\text { Parameters/Quantitative } \\
\text { Restriction }\end{array}$ & Ad-libitum & $90 \%$ ad libitum & $80 \%$ ad libitum & SEM \\
\hline Initial weight $(\mathrm{kg})$ & 6.44 & 7.00 & 6.72 & \pm 0.38 \\
Final weight $(\mathrm{kg})$ & 39.56 & 39.44 & 37.67 & \pm 1.91 \\
Weight gain $(\mathrm{kg})$ & 33.11 & 32.44 & 37.67 & \pm 1.74 \\
Daily weight gain $(\mathrm{kg})$ & 315.34 & 308.99 & 294.71 & \pm 0.02 \\
Feed intake $(\mathrm{kg} / \mathrm{pig})$ & 49.46 & 47.48 & 42.23 & \pm 3.40 \\
Daily feed intake $(\mathrm{g})$ & 471.02 & 454.06 & 402.22 & \pm 0.03 \\
FCR & 1.46 & 1.46 & 1.37 & \pm 0.05 \\
\hline
\end{tabular}

S.E.M= Standard error of mean 
Growth response of growing pigs to qualitative and quantitative feed restriction

Table 4: Interaction between qualitative and quantitative feed restriction on the performance of growing pigs

\begin{tabular}{|c|c|c|c|c|c|c|c|c|c|c|}
\hline \multirow[b]{2}{*}{ Qualitative Restriction (\%) } & & & & \multicolumn{7}{|c|}{ Qualitative $\mathrm{x}$ Quantitative } \\
\hline & & 20 & & & 18 & & & 16 & & \\
\hline $\begin{array}{l}\text { Parameters/Quantitative } \\
\text { Restriction }\end{array}$ & $\begin{array}{l}\text { Ad } \\
\text { libitum }\end{array}$ & $\begin{array}{l}90 \% \text { ad } \\
\text { libitum }\end{array}$ & $\begin{array}{l}80 \% A d \\
\text { libitum }\end{array}$ & $\begin{array}{l}\text { Ad } \\
\text { libitum }\end{array}$ & $\begin{array}{l}90 \% \mathrm{Ad} \\
\text { libitum }\end{array}$ & $\begin{array}{l}80 \% \mathrm{Ad} \\
\text { libitum }\end{array}$ & Ad libitum & $\begin{array}{l}90 \% \mathrm{Ad} \\
\text { libitum }\end{array}$ & $\begin{array}{l}80 \% \mathrm{Ad} \\
\text { libitum }\end{array}$ & SEM \\
\hline Initial weight(kg) & 6.67 & 6.67 & 7.00 & 6.67 & 7.00 & 6.83 & 6.00 & 7.33 & 6.33 & \pm 0.66 \\
\hline Final weight $(\mathrm{kg})$ & 44.33 & 44.33 & 40.33 & 39.00 & 39.00 & 37.33 & 35.33 & 35.00 & 35.33 & \pm 3.31 \\
\hline Weight gain $(\mathrm{kg})$ & 37.67 & 37.67 & 33.33 & 32.33 & 32.00 & 30.50 & 29.33 & 27.67 & 29.00 & \pm 3.01 \\
\hline Daily weight gain $(\mathrm{kg})$ & 358.73 & 358.73 & 317.46 & 307.94 & 304.76 & 290.48 & 279.37 & 263.49 & 276.19 & \pm 0.03 \\
\hline Feed intake $(\mathrm{kg})$ & $62.84^{\mathrm{a}}$ & $56.98^{\mathrm{ab}}$ & $47.62^{\mathrm{ab}}$ & $44.68^{\mathrm{ab}}$ & $47.00^{\mathrm{ab}}$ & $38.48^{\mathrm{b}}$ & $40.85^{\mathrm{b}}$ & $39.05^{\mathrm{b}}$ & $40.60^{b}$ & \pm 6.23 \\
\hline Daily feed intake ( $\mathrm{g}$ ) & $598.48^{\mathrm{a}}$ & $542.67^{\mathrm{ab}}$ & $453.52^{\mathrm{ab}}$ & $425.52^{\mathrm{ab}}$ & $447.62^{\mathrm{ab}}$ & $366.48^{\mathrm{b}}$ & $389.05^{\mathrm{b}}$ & $371.90^{\mathrm{b}}$ & $386.67^{\mathrm{b}}$ & \pm 0.06 \\
\hline FCR & $1.66^{\mathrm{a}}$ & $1.51^{\mathrm{ab}}$ & $1.43^{\mathrm{ab}}$ & $1.35^{\mathrm{b}}$ & $1.47^{\mathrm{ab}}$ & $1.26^{\mathrm{b}}$ & $1.37^{\mathrm{b}}$ & $1.41^{\mathrm{ab}}$ & $1.41^{\mathrm{ab}}$ & \pm 0.08 \\
\hline
\end{tabular}

ab-Values with different superscripts within rows are significantly different $(\mathrm{P}<0.05)$

Table5: Effect of qualitative feed restriction on nutrient digestibility of growing pigs

\begin{tabular}{lllll}
\hline Parameters/ Qualitative & $20 \%$ C.P. & $18 \%$ C.P. & $16 \%$ C.P. & S.E.M \\
\hline Feed Intake(kg) & 1.55 & 1.36 & 1.19 & \pm 0.03 \\
Dry matter Intake(kg) & 1.49 & 1.29 & 1.11 & \pm 0.03 \\
Excreted faeces(kg) & $1.11^{\mathrm{a}}$ & $0.74^{\mathrm{b}}$ & $0.67^{\mathrm{b}}$ & \pm 0.06 \\
FaecalDry matter output(kg) & $0.81^{\mathrm{a}}$ & $0.45^{\mathrm{b}}$ & $0.31^{\mathrm{b}}$ & \pm 0.04 \\
Excreted faeces/ dry matter intake & $0.7^{\mathrm{a}}$ & $0.59^{\mathrm{b}}$ & $0.58^{\mathrm{b}}$ & \pm 0.05 \\
(\%) & & & $66.94^{\mathrm{b}}$ & \pm 2.70 \\
Dry matter digestibility (\%) & $73.63^{\mathrm{a}}$ & $71.99^{\mathrm{ab}}$ & $76.42^{\mathrm{b}}$ & \pm 1.51 \\
Crude protein digestibility (\%) & $79.92^{\mathrm{a}}$ & $78.91^{\mathrm{a}}$ & $76.46^{\mathrm{a}}$ & \pm 2.37 \\
Ether extract (\%) & $60.59^{\mathrm{b}}$ & $73.30^{\mathrm{ab}}$ & $49.98^{\mathrm{b}}$ & \pm 2.87 \\
Crude fibre digestibility (\%) & $61.76^{\mathrm{a}}$ & $57.97^{\mathrm{a}}$ & $63.60^{\mathrm{a}}$ & \pm 2.04 \\
Ash (\%) & $40.29^{\mathrm{b}}$ & $58.55^{\mathrm{a}}$ & & \\
\hline
\end{tabular}

${ }^{\mathrm{ab}}$ Means on the same row having different superscripts are significantly different $(\mathrm{p}<0.05)$. 
level of qualitative feed restriction but the excreted faeces, faecal dry matter output, excreted faeces/ dry matter intake, dry matter digestibility, crude protein digestibility, ether extract, crude fibre digestibility and ash were significantly $(\mathrm{P}<0.05)$ influenced with the level of qualitative restriction. Feed intake value $(\mathrm{P}>0.05)$ of $1.55 \mathrm{~kg}$ was recorded for pigs fed with $20 \%$ crude protein diet while those fed with $18 \%$ and $16 \%$ crude protein had feed intake of $1.36 \mathrm{~kg}$ and $1.19 \mathrm{~kg}$, respectively. Similar $(\mathrm{P}>0.05)$ values of dry matter digestibility, crude protein and crude fibre digestibility were observed for pigs fed $20 \%$ and $18 \%$ dietary protein, these differed significantly from the values documented for pigs on $16 \%$ dietary protein diet. Highest $(p<0.05)$ mean values in excreted faeces/dry matter intake, dry matter digestibility and faecal dry matter output were recorded for pigs fed $20 \%$ crude protein.

Effect of Quantitative Feed Restriction on Nutrient Digestibility of Growing Pigs

Effect of quantitative feed restriction on nutrient digestibility of growing pigs is shown in Table 6. Feed intake and dry matter were not significantly $(\mathrm{P}>0.05)$ influenced by the level of restriction while excreted faeces, faecal dry matter output, excreted faeces/dry matter intake, dry matter digestibility, crude protein, ether extract, crude fibre digestibility and ash were significantly $(\mathrm{P}<0.05)$ affected by the levels of restriction. Excreted faeces values $(1.01,0.80$ and $0.71 \mathrm{~kg})$ decreased significantly with decreasing level of feed intake.Excreted faeces values of pigs fed $90 \%$ and $80 \%$ ad-libitum were statistically similar $(\mathrm{P}>0.05)$. Comparable $(\mathrm{P}>0.05)$ mean values of dry matter digestibility (78.11, 78.69\%), ether extract (77.42, $77.66 \%)$ and crude fibre digestibility $(61.65,61.65 \%)$ were recorded for pigs fed $80 \%$ and $90 \%$ of ad libitum respectively which differed statistically $(\mathrm{p}<0.05)$ from the values (55.77, 55.28 and $46.40 \%$, respectively) obtained for pigs fed ad libitum. Highest $(\mathrm{P}>0.05)$ value of crude protein digestibility $(85.60 \%)$ was recorded for pigs fed $90 \%$ of ad-libitum.

Interaction between Qualitative and Quantitative Feed Restriction on Nutrient Digestibility of growing pigs

Table7shows the interaction between qualitative and quantitative feed restriction on nutrient digestibility of growing pigs. The interaction between qualitative and quantitative restriction had no significant $(\mathrm{P}>0.05)$ effect on nutrients digestibility parameters of growing pigs considered.

Table 6: Effect of quantitative feed restriction on nutrient digestibility of growing pigs

\begin{tabular}{lllll}
\hline Parameters/Quantitative & Ad-libitum & $\begin{array}{l}90 \% \text { Ad- } \\
\text { libitum }\end{array}$ & $\begin{array}{l}80 \% \text { Ad- } \\
\text { libitum }\end{array}$ & S.E.M \\
\hline Feed Intake(kg) & 1.38 & 1.37 & 1.34 & \pm 0.03 \\
Dry Matter Intake(kg) & 1.32 & 1.30 & 1.28 & \pm 0.04 \\
Excreted Faeces (kg) & $1.01^{\mathrm{a}}$ & $0.80^{\mathrm{b}}$ & $0.71^{\mathrm{b}}$ & \pm 0.07 \\
Faecal Dry matter output $(\mathrm{kg})$ & $0.65^{\mathrm{a}}$ & $0.54^{\mathrm{a}}$ & $0.38^{\mathrm{b}}$ & \pm 0.10 \\
Excreted Faeces/dry matter intake(kg) & $0.76^{\mathrm{a}}$ & $0.61^{\mathrm{b}}$ & $0.55^{\mathrm{b}}$ & \pm 0.40 \\
Dry matter digestibility (\%) & $55.77^{\mathrm{b}}$ & $78.11^{\mathrm{a}}$ & $78.69^{\mathrm{a}}$ & \pm 7.12 \\
Crude protein digestibility (\%) & $72.03^{\mathrm{c}}$ & $85.60^{\mathrm{a}}$ & $78.60^{\mathrm{b}}$ & \pm 3.46 \\
Ether extract (\%) & $55.28^{\mathrm{b}}$ & $77.42^{\mathrm{a}}$ & $77.66^{\mathrm{a}}$ & \pm 9.72 \\
Crude fibre digestibility (\%) & $46.40^{\mathrm{b}}$ & $61.65^{\mathrm{a}}$ & $61.65^{\mathrm{a}}$ & \pm 5.22 \\
Ash (\%) & $48.61^{\mathrm{b}}$ & $50.88^{\mathrm{b}}$ & $62.95^{\mathrm{a}}$ & \pm 5.71 \\
\hline abc Means on the same row having different superscripts are significantly different $(\mathrm{P}<0.05)$ \\
S.E.M: standard error mean
\end{tabular}


Growth response of growing pigs to qualitative and quantitative feed restriction

Table 7: Interaction between qualitative and quantitative feed restriction on nutrient digestibility of growing pigs

\begin{tabular}{|c|c|c|c|c|c|c|c|c|c|c|}
\hline Qualitative & $20 \%$ & & & $18 \%$ & & & $16 \%$ & & & \\
\hline Quantitative & $\begin{array}{l}\text { Ad- } \\
\text { libitum }\end{array}$ & $\begin{array}{l}90 \% \\
\text { ad- } \\
\text { libitum }\end{array}$ & $\begin{array}{l}80 \% \\
\text { ad-libitum }\end{array}$ & $\begin{array}{l}\text { Ad- } \\
\text { libitum }\end{array}$ & $\begin{array}{l}90 \% \\
\text { ad-libitum }\end{array}$ & $\begin{array}{l}80 \% \\
\text { ad-libitum }\end{array}$ & $\begin{array}{l}\text { Ad- } \\
\text { libitum }\end{array}$ & $\begin{array}{l}90 \% \\
\text { ad-libitum }\end{array}$ & $\begin{array}{l}80 \% \\
\text { ad-libitum }\end{array}$ & S.E.M \\
\hline Parameters/ Treatments & 1 & 2 & 3 & 4 & 5 & 6 & 7 & 8 & 9 & \\
\hline Feed Intake(kg) & 1.60 & 1.30 & 1.25 & 1.50 & 1.36 & 1.26 & 1.55 & 1.41 & 1.06 & \pm 0.10 \\
\hline Dry matter Intake(kg) & 1.54 & 1.24 & 1.17 & 1.44 & 1.30 & 1.18 & 1.49 & 1.35 & 0.99 & \pm 0.95 \\
\hline Excreted faeces $(\mathrm{kg})$ & 1.29 & 0.90 & 0.82 & 1.09 & 0.65 & 0.66 & 0.04 & 0.68 & 0.52 & \pm 0.05 \\
\hline $\begin{array}{l}\text { Faecal dry matter } \\
\text { output(kg) }\end{array}$ & 1.10 & 0.43 & 0.44 & 0.78 & 0.57 & $\mathrm{~s} 0.27$ & 0.55 & 0.37 & 0.23 & \pm 0.01 \\
\hline $\begin{array}{l}\text { Excreted faeces/ dry } \\
\text { matter intake (\%) }\end{array}$ & 0.84 & 0.73 & 0.70 & 0.76 & 0.50 & 0.56 & 0.62 & 0.50 & 0.52 & \pm 0.02 \\
\hline $\begin{array}{l}\text { Dry matter digestibility } \\
(\%)\end{array}$ & 44.50 & 63.55 & 59.25 & 77.1 & 75.25 & 81.99 & 79.22 & 77.18 & 79.66 & \pm 0.50 \\
\hline $\begin{array}{l}\text { Crude Protein } \\
\text { digestibility (\%) }\end{array}$ & 67.01 & 76.27 & 72.82 & 85.93 & 67.02 & 86.16 & 72.59 & 79.94 & 80.44 & \pm 0.50 \\
\hline Ether extract (\%) & 30.83 & 72.95 & 62.17 & 79.08 & 67.01 & 86.16 & 72.59 & 79.94 & 80.44 & \pm 0.72 \\
\hline $\begin{array}{l}\text { Crude Fiber digestibility } \\
(\%)\end{array}$ & 34.83 & 49.05 & 55.32 & 63.21 & 63.80 & 57.94 & 51.89 & 61.05 & 72.01 & \pm 0.68 \\
\hline Ash (\%) & 25.99 & 56.05 & 63.78 & 37.94 & 54.67 & 60.04 & 56.95 & 64.92 & 66.98 & \pm 0.81 \\
\hline
\end{tabular}




\section{Discussion}

Pigs fed higher dietary proteinconsumed more feed and gained more weight than those on less protein diets. The variation in feed intake and weight gain could be attributed to more amino acid intake by the pigs on higher plane of nutrition. The growth of pig is related to the voluntary feed intake which supports the evidence that the weight gain of fast growing animals could be inhibited by feed restriction (Lebret et al., 2008). The pigs on lowercrude protein diets could have been subjected to inadequate and non-essential amino acid leading to deterioration in their weight gain. Proteins are major component in muscle which is highly need at early than late phase of growth (Damgaard, 1997). The observed differences in feed intake and weight gain with increasing levels of dietary crude protein is in line with the studies of Nyachoti et al. (2006) and Nguyen et al. (2003) who reported a linear reduction in average daily feed intake and average daily weight gain of piglets with decreasing level of dietary crude protein. Temim et al. (2000) observed that increase in protein supply from 10 to $33 \%$ improved growth performance and carcass characteristics of boilers reared in a hot environmental condition at thermoneutrality. On the other hand, Le Bellego et al. (2002) found no adverse effect on piglet performance by lowering the crude protein level of diet from 22.4 to $16.9 \%$. On the contrary, Forbes (1995) and Carpenter et al. (2004) reported a linear increase in feed intake to decreasing crude protein concentration. The differences in these studies may be due to the environment, genotype or breed or age of pigs used which differed. The results of this present study indicate that increase in dietary protein level resulted to increase in weight gain and a better feed conversion ratio of pigs. This result is in agreement with that of De silva and Perera (1985) and Zhang et al. (2013) who stated that FCR decreased with increasing level of crude protein in the diet.

The obtained results of this experiment showed that body weight gain, feed intake and feed conversion ratio were not affected by quantitative feeding regimen.The pigs on 80 and $90 \%$ ad libitum feeding must have obtained sufficient nutrients required for maintenance and tissue growth, leading to comparable mean values in the growth parameters considered.In agreement with Daza et al. (2003), Bee et al. (2007) and Serrano et al. (2009) feed restriction did not affect growth indices in this study, indicating that moderate quantitative feed restrictions have little or no effect on growth performance traits. On the other hand, Daza et al. (2003), Njoku et al. (2013) and Omosebi et al. (2014)reported that severe feed restriction (46 or $40 \%$ of ad libitum feed offered) impaired the growth performance of pigs and broiler birds.

The digestibility of nutrients is an important measure of livestock production efficiency. The comparable mean values obtain for feed intake and dry matter intake in this present study are in line with the study of Sharifi et al. (2013), the feed intake and dry matter intake increasednumerically with increasing level of dietary protein. It has been reported that feed intake increases with increase in dietary crude protein level in some ruminants (Huston et al., 1988; Cheemaet al., 1991; Negesseset al., 2001). However, the recent findings in this study corroborate the report of Hwangboet al. (2009) that increasing crude protein levels from 14 to $20 \%$ had no significant effect on dry matter intake of Korean Black goats. The significant differences observed in total faeces excreted, faecal dry matter output and excreted faeces/ dry matter intake can be linked with the level of dry 
matter intake which increased with increasing level of dietary crude protein. Kreuzer (1986) observed that faecal output and dry matter content of faeces increased with increasing dry matter intake. So faecal output can reflect nutrient manipulation of diets (Nyachoti et al., 2006) and feed intake (Hsiah and Lu, 1989). In this study, the digestibility of dry matter, crude protein and crude fibre increased significantly with increase in crude protein content in diets. These observations are in line with the report of Zhang et al. (2013) who reported a decrease in dry matter, crude protein and crude fibre digestibility with decreasing dietary protein level.Szymeczko and Skrede (1991) reported a slight reduction in the crude protein digestibility of fox at a declining protein levels. The better crude protein digestibility in the diets containing high protein may be connected to the oxidation of amino acid excesses. A reduction in dietary crude protein has been reported to increase the relative amount of endogenous nitrogen secretion which might have led to reduction in apparent crude protein digestibility (Low,1980; Baker, 1989). The increased in crude fibre digestibility could be linked to the level of crude fibre in the diets which increased with increasing crude protein level. The increasing dietary crude fibre could have a positive effect on the intestinal microflora and intestinal health of the pigs where it helps in providing substrate for beneficial microorganism which helps to improve intestinal lining, thus improving digestion and growth performance of animal (Michard, 2010; Kroismayr, 2011). A review by Whittemore et al. (2001) asserts that increasing diet crude fibre content will increase gut motor functionality, decrease transit time, increase water holding capacity and the proportion of digestible nutrients appearing in the large intestine. In contrast to this study, Mohiti-Asli et al.(2012) reported increased crude fibre digestibility as the nutrition plane of dietary crude protein is reduced.Lipids are required by pigs as a source of available energy, as structural components of bio-membranes, carriers of fat-soluble vitamins, precursors to eicosanoids, hormones and vitamins, and as enzyme co-factors (Lovell, 1989). In this study, the ether extract digestibility decreased with increasing crude protein levels in the diet, this could be associated to the source and inclusion levels of dietary fat in the diets. This may indicate that crude fat from Groundnut cake were not fully available for the digestive enzymes of the pigs.Abu et al. (1984) reported that the level of ether extract digestibility increased as the level of oil palm slurry increased in the diets. Mateos and Sell (1980) enthused that high-oil diets contain extra-caloric effect produce a better fat metabolism.

The digestibility of nutrients improved with level of restriction, this is in agreement with previous studies by Tumovaet al. (2003 and 2007). The improvement in the dry matter digestibility, ether extract, ash and crude fibre digestibility of pigs on limited feed offered could be associated with slower movement of digesta when feed quantity is reduced, allowing for a more complete and efficient digestion in the hindgut (Lewis and Dehority.,1985). Thacker (2009) and den Hartoget al. (1988) also asserted that improvements in nutrient digestibility have been generally attributed to delay in gastric emptying which was postulated to be the result of slow passage through the small intestine allowing more time for nutrients breakdown. Njokuet al. (2012) reported that when feed intake is reduced below maintenance level, animal tends to become more efficient in digestion and in utilizing the nutrients, this observation is also in line with Murphy et al. (1994) who reported that 
increasing intake above maintenance level led to decrease in digestibility of varying degrees depending on type and quality of diet fed.

\section{Conclusion}

This study has shown that qualitative feed restriction influenced weight gain, feed intake and feed to gain ratio of growing pigs while quantitative restriction had no effect on growth indices of growing pigs Also, all the nutrient digestibility parameters considered were influenced by quantitative and qualitative feed restriction of the pigs except feed intake and dry matter intake.Thus, nutrient intake limitation strategies (both qualitative and quantitative) should be used to improve the productivity of farm animals.

\section{References}

Abu, A.A., Okai, D.B. and Tuah, A.K. 1984. Oil palm slurry (OPS) as a partial replacement for maize in the diets of growing-finishing pigs. Nutritional Reports International 30(1):121-127

AOAC 2005. Official Method of Analysis of $\mathrm{AOAC}$, International official m e thod $982.30 \quad(\mathrm{a}, \mathrm{b}, \mathrm{c})$ $18^{\text {th }}$ edition.AOAC international Gaithersburg, M.D.

Mohiti-Asli, M., Shivazad, M., Zaghari, M., Aminzadeh, S., Rezaian, M. and Mateos,G.G. 2012. Dietary fibers and crude protein content alleviate hepatic fat deposition and obesity in broiler breeder hens. Poultry Science 91(12):3107-3114

Baker, D. H. 1989. Amino acid nutrition of pigs and poultry. In: Haresign, W. and
Cole, D. J. A. (ed.) Recent advances in animal nutrition. Butterworths, Borough Green, Sevenoaks, Kent TN158PH, England. 298

Bee, G., Calderini, M., Biolley, C. Guex, G., Herzog, W., Lindemann, M. D. 2007. Changes in the histochemical properties and meat quality traits of porcine muscles during the growingfinishing period as affected by feed restriction, slaughter age, or slaughter weight. Journal of Animal Science 5: 1030-1045.

Cai, W., Casey, D.S. and Dekkers J.C. 2008. Selection response and genetic parameters for residual feed intake in Yorkshire swine. Journal of Animal Science 86:119-135

Carpenter, D.A., O'Mara, F.P. and O'Doherty, J.V. 2004. The effect of dietary crude protein concentration on growth performance, carcass composition and nitrogen excretion in entire grower-finisher pigs. Irish Journal of Agricultural and Food Research 43:227-236

Cheema, A.U., Galyean. M.L. Caton, J.S, Freeman. A.S. 1991. Influence of protein levels and naloxone on intake,nitrogen metabolism and digestion kinetics in lambs fed oat, hay and barley straw. J. Small Rumin. Res. 5: 35-46

Damgaard, B. 1997. Dietary protein supply to mink (Mustela vison) Effects on physiological parameters, growth performance and health. Ph. D. Thesis. Department of Animal Science and Animal Health, the Royal Veterinary and Agricultural University, Frederiksberg C, Denmark. 31

Daza, A., I. Rodriguez, I. Ovejero, and C. J. Lopez-Bote. 2003. Effecton pig performance of feed restriction during 
the growth period. Span. J. Agric. Res. $1: 3-8$.

De Silva, S. S. and Perera, M. K. 1985. Effects of dietary protein levels on growth, food conversion and protein use in young Tilapia nilotica at four salinities. Trans. Am. Fish. Soc. 114 : 589-589.

Duncan, D.B. 1955. New multiple Range Test Biometrics 11:1-42

Forbes, J.M. 1995. Voluntary Food Intake and DietSelection in Farm Animals. $\mathrm{CAB}$ International, Wallingford, pages 226-246.

Gonzales A. J, Alcalbet, $J$ and Neilsien,B.1999. Metabolic and thermodynamics responses to dehydration- induced reductions in muscle blood flow in exercising humans. Journal of Physiology, 52(2): 577-589

Hsia, L. C. and Lu, G. H. 1989. The effects of season, sex and breed on pig food intake and performance. In Thevoluntary food intake of pigs (ed. J. M. Forbes, M. A. Varley and T. L. J. Lawrence), British Society of Animal Production,Occasional Publication 13: 119-120

Hoque, M. A., H. Kadowaki, T. Shibata, T. Oikawa, and K. Suzuki.2009. Genetic parameters for measures of residual feed intake and growth traits in seven generations of Duroc pigs. Livestock Science 121:45-49.

Huston, J.E, Engdahi G.S and Bales K.W. 1988. Intake and digestibility in sheep and goats fed three forages withdifferent levels of supplemental protein.J. Small Ruminant Res. 1:8192

Hwangbo, S. Choi S.H., Kim S.W, Son D.S, Park H.S, Lee S.H and Jo I.H 2009. Effects of crude proteinlevels in the total mixed rations on growth performance and meat quality in growing Korean black Goats.AsainAust.Journal of Animal science 22:1133-1139

Kreuzer, M. 1986. Effect of defunation on the loss of energy in weters fed different quantities of cellulose and normal or stream-flaked maize starch. Anim. Feed Sci. Technol. 16:233-241

Kroismayr, A. 2011. Total dietary fibre in poultry nutrition-formulating outside the crude fibre box. Asian Feed Inc. Bulletin March/April :3-5

Le Bellego, L., van Milgen, J. and Noblet J. 2002. Effect of high temperature and low- protein diets on the performance of growing-finishing pigs. J. Anim. Sci. 80:691-701.

Lebret, B. 2008.Effects of feeding and rearing systems on growth, carcass compositionand meat quality in pigs. Animal, 2(10): 1548- 1558

Leeson, S. and K. Zubair, 1997. Nutrition of the broiler chicken around the period of compensatory growth. Poultry Science 76: 992-999.

Lewis, S.M. and Dehority.B.A. 1985. Microbiology and ration digestibility in the hindgut of the ovine.Applied Environmental Microbiology 50:356

Lovell, R.T. 1989. Nutritional and feeding of fish. Van Nostrand-Reinhold, New York PP:260

Low, A. G. 1980. Nutrient absorption in pigs. J. Sci. Food Agric. 31: 1087-1130.

Mateos , G.G. and Sell, J.L. 1980. Influence of carbohydrate and supplemental fat source on the metabolizableenergy of the diet.Poultry Science 59:2129-2135

Michard, J. 2010. Dietary fibre- the forgotten nutrientfi International 
Poultry Production 19:24-27

Murphy, T.A., Loerch, S.C. and Smith, F.E. 1994. Effects of feeding high concentrate diet at restricted intakes ondigestibility and nitrogenous metabolism in growing lambsJournal of Animal Science 72: 1583- 1590

Negesses T., Rodehuts Cord, M. Pfeffer E. 2001. The effects of dietry crude protein level on intake and growth,protein retention and utilization of growing male sannen kids J. Small Ruminant Res. 1:8-92

Njoku, C.P, Sogunle O.M.O, Adeyemi O. A, Aina A. J. B, and Oduguwa O. O. 2012. Response of growing pigs reared in humid tropical environment to different feeding frequencies. International Journal of Applied Animal Sciences, 1(4): 102-107

Njoku , C.P, Aina A.B.J, Sogunle, O.M., O.A. Adeyemi and O.O. Oduguwa. 2013. Evaluation of feed quantity offered, feeding frequency and duration of feeding on the performance of growing pigs. Thai Journal of Agricultural Science 46(4):181-190

Nguyen C.V., Biernat $M$ and Smulikowska S., 2003. Influence of feeding full-fat linseed and rapeseed on the morphology of small intestinal mucosa in broiler chickens. J. Anim. Feed Sci. 12: 573- 582

Nyachoti, C.M., Artnfield, S.D., and Guenter, W. 2006. .Effect of micronized pea and enzyme supplementation on nutrient utilization and manure output in growing pigs. Journal of Animal Science 84: 2150-2156.

Omosebi D.J., Adeyemi O.A., Sogunle M.O., Idowu O.M.O. and Njoku C.P. 2014. Effects of duration and level of feed restriction on performance and meat quality of broiler chickens. Archivos de Zootecnia 63(244): 611-621

Richards, M.P. 2003. Genetic regulation of feed intake and energy balance in poultry. Poultry Science 82:907-916.

SAS Institute Inc. 2000. SAS/STAT ${ }^{\circledR}$ User's Guide, Vers.8, 4th Ed. Cary, NC, SAS Institute Inc. 17:116-121

Scott, B.D., Potter, G.D and Evans, J.W. 1989. Growth and feed utilization by yearling horses fed added dietary fat. J. Equine Vet. Sci. 9(4): 210-214

Serrano, M.P., Valencia, D.G., Fuentetaja, A., Lazaro, R. Mateos, G.G. 2009. Journal of Animal Science 87:16761685

Sharifi, M., Bashtani, M., Naserian, A.A. and Khorasani, H. 2013. Effect of dietary crude protein level on the performance and apparent digestibility of Iranian Saanen kids. African Journal of Biotechnology Vol. 12(26): 4202-4205

Szymeczko, R. and Skrede, A. 1991. Protein digestion in fistulated polar foxes. Scientifur 15: 227-232.

Temim,S., Chagneau, A.M., Guillaumin, S., Michel, J., Peresson, R. and Tesseraud, S. 2000. Does excess dietary protein improve growth performance and carcass characteristics in heat-exposed chickensfi.Poultry Science 79:312-317

Thacker, P.A. 2009. Effects of supplementary Threonine, canola oil on nutrient digestibility, performance andcarcass traits of growing- finishing pigs fed diets containing wheat distillers' grain with soluble. AsianAustrian Journal of Animal Science 22(12): 1676-1685

Tumova, E., Skrivanova, V and Skriran, M., 2003. Effect of restricted feeding 
time and quantitative restriction in growing rabbits. Archive-FurGeflugelkunde 67 (4):182-190.

Tumova E, Zita, L., Skrivanova, V., Fucikova, A., Skrivan, $M$ and Buresova, M. 2007.Digestibility of nutrients, organ development and blood picture in restricted and adlibitum fed broiler rabbits. Arch. Geflugelk 71(1):6-12

Whittemore, C.T., Green, D.M. and Knap, P.W. 2001. Technical review of the energy and protein requirements of growing pigs: food intake. Animal Science 73:199-215

Zhang, G.J., Xie, C.Y., Thacker, P.A., Htoo, J.K. and Qiao, S.Y. 2013. Estimation of the ideal ratio of standardized ileal digestible threonine to lysine for growing pigs $(22-50 \mathrm{~kg})$ fed low crude protein diets supplemented with crystalline amino acids. Animal Feed Science and Technology 180:83-91 